\title{
A Case Study for the Use of Technology Supported Graphical Organizers in Preschool Children's Problem Solving
}

\author{
Ekmel ÇETIN * 1 (i) Selçuk ÖZDEMIR 2 \\ ${ }^{1}$ Kastamonu University, Faculty of Education, Kastamonu, Turkey, ekmel@kastamonu.edu.tr \\ ${ }^{2}$ Gazi University, Faculty of Education, Ankara, Turkey, sozdemir@gazi.edu.tr \\ * Corresponding Author: ekmel@kastamonu.edu.tr
}

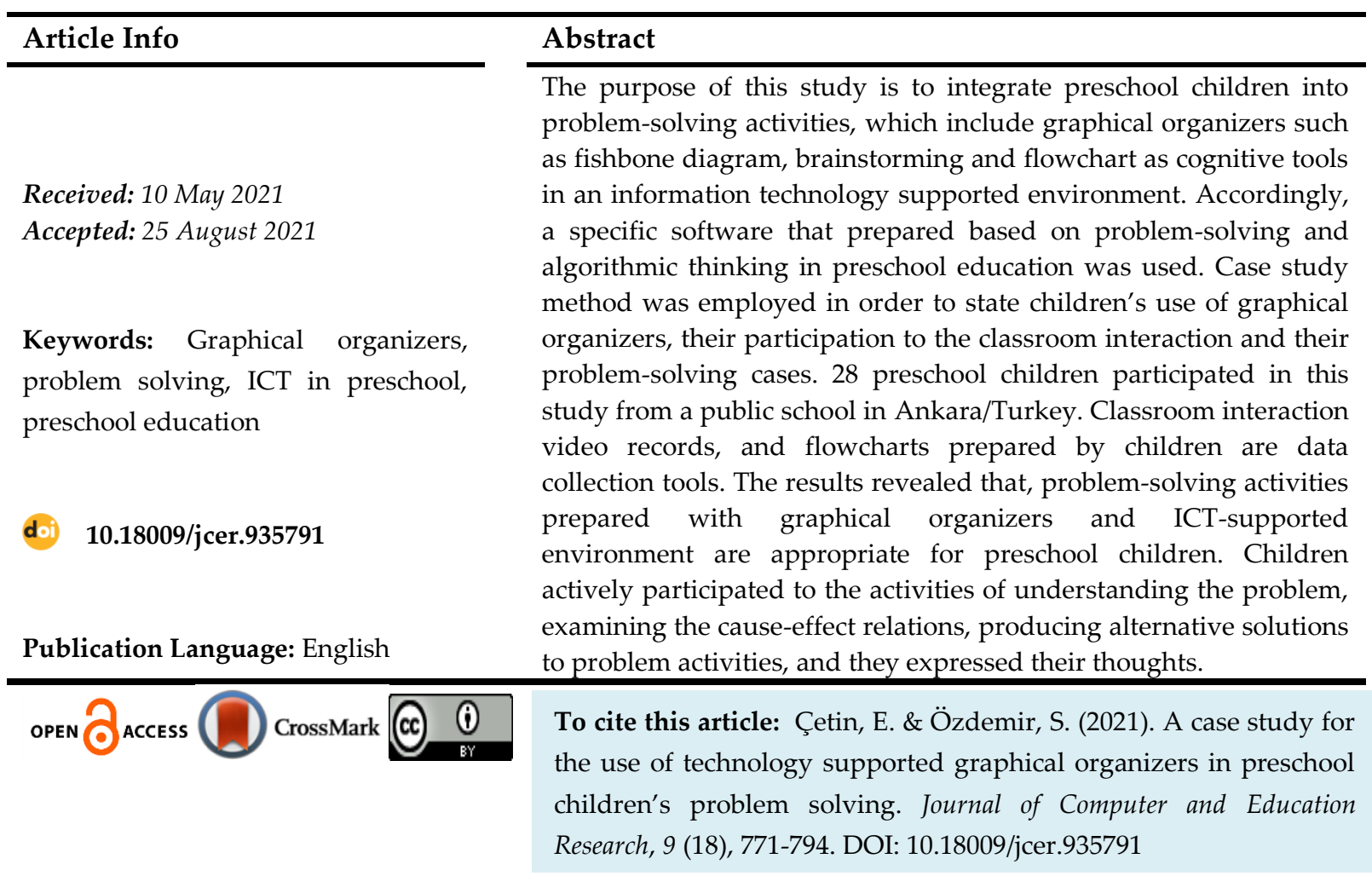

\section{Introduction}

Preschool education aims to ensure that children acquire body, mind and emotion development and good habits according to their development characteristics. Preschool period is the most intense and rapid period of brain development and the establishment of synaptic connections. It is a vitally important period for the development of cognitive functions as predictors of academic skills in later years (Allan, Hume, Allan, Farrington \& Lonigan, 2014). The development of brain forms a strong foundation for cognitive, language, psychomotor, social and emotional development of the child. Thus, preschool children take the first step towards realizing their own potential and joining the society as a productive individual. Considering the cognitive characteristics to be acquired in preschool children, characteristics such as pairing, relationship building, establishing cause-effect relations, reading object graph, and graphing are observed Ministry of National Education [MoNE] 
2013). These cognitive characteristics and cognitive functions should be supported in the early childhood period (Sezgin \& Ulus, 2020). One of the key concepts in cognitive functions is the problem-solving ability of learners (Haywood, 2020).

Problem solving as the basis of all high-level thinking skills, has been studied in various dimensions (interpersonal problem solving, social problem solving, etc.) at preschool education institutions. Problem situations should be given to develop the problem solving skills of children by giving problem-solving education in a planned curriculum instead of leaving children in their play environments (Alnıak \& Dinçer, 2005). For instance, Social Skills Education Program is a planned set of different activities for dealing with problematic behaviors in preschool children and it has a positive effect on children's interpersonal problem solving skills (Özbey \& Köyceğiz-Gözeler, 2020). As preschool period is a period in which children interact with each other intensively, problem-solving activities which are based on cooperation and which support children's speeches are also important (Kinnucan, 2012; Ramani, 2005). It was also observed that problem solving was a complex process and that children did not improve when the developmental characteristics of children were not taken into consideration (Johnson, 2013). Studies show that problem solving activities should take place in preschool period but should be prepared by considering some situations. Interpersonal problem solving skills are the most studied subject in early childhood but this study will focus on social problem solving skills with the help of technology supported environments.

According to Baralt (2013), there are many scaffolding ways in preschool period to encourage children for problem-solving. One way to adapt problem-solving activities appropriate for children's developmental characteristics is the use of mediators. It is recommended to use visual materials as external tools in problem-solving activities (Angeli \& Valadines, 2004). Graphical organizers such as fishbone, Venn diagram, flowchart, concept map, which are effective visual materials, are also used as supportive materials for children's problem solving. Graphical organizers make it easier for children to learn in problem-solving activities by scaffolding of teacher (Zollman, 2009). Research shows that educational software, which includes such cognitive tools prepared for preschool education, is effective in children's learning and development (Dong, 2018).

Use of Information and Communication Technologies (ICT) at early ages, contributes to different developmental characteristics of children. Studies include curriculum proposals 
for the use of ICT in preschool education (Dong \& Newman, 2016; Lin, 2012) and studies about the role of preschool teachers in this curriculum (Cviko, McKenney \& Voogt, 2014) are already available. Studies on integrating ICT in preschool education show that informatics contributes to children's learning and development (Hsin, Li \& Tsai, 2014). Positive effects of the use of ICT on children in teaching of basic science and mathematics concepts in preschool were observed in studies (Nikolopoulou, 2020). The opinions of preschool teachers also support the use of ICT as support material in classroom (Nikolopoulou, 2020; Nikolopoulou \& Giamalas, 2015). There are also studies on thinking skills such as problem solving (Fessakis, Gouli \& Mavroudi, 2013), creative-thinking (Liu, Lin, Liou, Feng \& Hou, 2013) and geometric-thinking (Keren \& Fridin, 2014) with the support or the use of ICT.

Consequently, there should be problem-solving activities in preschool education, and these activities should be supported with the new information and communication technologies. In particular, there is a need for a curriculum and instructional design will be appropriate to developmental characteristics of children. This instructional design should enable children to discipline their thinking processes and to embody the steps of thinking. Therefore, the problem sentence of this study is determined as follows: What are the cases of using graphical organizers (fishbone, brainstorming, and flowchart) and solving problems for different problem situations encountered by preschool children? The aim of this study is to examine the usage situations of graphical organizers such as fishbone, brainstorming and flowchart against the problems faced by preschool children. For this general purpose, following research questions will be answered:

- What are the problem-solving situations of preschool children using graphical organizers in a technology-supported environment?

- What are the problem-solving situations of preschool children after the activities in a software-independent environment?

\section{Cognitive Development, Problem-Solving and Social Learning Theory}

According to Jean Piaget, cognitive development is explained according to the stages and there are qualifications to be acquired at each stage. Piaget says that not supporting cognitive development in a particular phase will have a negative impact on the child's future life (Cook-Cottone, 2004). The age group of the study (60-72 months) corresponds to preoperational period (2-7 years) according to Piaget. Developments in children's thinking appear in this period. Especially in the previous period, trial-error style problem solving has 
disappeared (Cook-Cottone, 2004). Schewebel and Raph (1973) recommend preparing active learning environments to support pre-operational characteristics such as perception-based thinking, logical thinking, classification, and conservation.

According to Getzels (1982), problem is divided into three types: presented, discovered and created. It is more important when the problem is created or discovered by the child. Thus, even if the children are not in a formal classroom order, the problem should be explored with various mediators or presentations. Shared activities provide children with the opportunity to learn, practice and improve their social and communication skills. Active role of children in social interactions will contribute positively to their development (Rogoff, 1998). Preschool children spend a lot of time together to interact, cooperate and solve problems before they go to primary school (Howes, Unger \& Matheson, 1992). In an environment where the interaction number is so high, problem-solving activities are expected to base on these environmental characteristics.

Social context has a significant effect from first stage of the problem-solving process. In that context, how the problem is understood and how the solution is found within the group may even change (Pretz, Naples \& Sternberg, 2003). Furthermore, social context has an important place in preschool mental activities such as problem solving. According to Vygotsky (1978), students build their own knowledge, and learning is a social activity. Social experiences and verbal interactions are important in shaping thoughts. According to Vygotsky, "a child's speech is an indispensable part of the problem-solving process" (Vygotsky \& Luria, 1994). Therefore, it is recommended to encourage children to talk even when thinking about problem-solving activities (Bodrova \& Leong, 1996). Using different cognitive tools with the possibilities of technology equipped social context and speech activities, richer environments may be created for problem solving.

\section{Graphical/Schematic Organizers}

Graphical or schematic organizers are visual tools that show information in various ways. Concept maps, mind maps, fishbone diagram, Venn diagram, flowcharts are the examples of schematic organizers (Dexter \& Hughes, 2011). The fact that schematic organizers make texts quite easy is crucial for preschool period. The use of schematic organizers in preschool period plays an important role in the transfer of concepts to children. A good visual presentation brings out key elements and their relationships in the way that 
words cannot be done alone (Jones, Pierce \& Hunter, 1988/89). Preparing schematic organizers that can achieve this is to carry out an important task to provide effective material for preschool education. According to Bodrova and Leong (1996), the tool between an environmental stimulus and the individual response to that stimulus is called as a mediator. Mediators help children to solve problems and turn low-level mental functions into advanced ones. Visual materials can be used as external mediators.

Fishbone diagram, brainstorming technique and flowchart are used in this study. Fishbone diagram is a cognitive tool developed by Ishikawa (1968) for use in the product design and quality control processes, with the actual name Ishikawa diagram. It facilitates the examination of factors causing the problem in problem-solving process on a single diagram. Simplicity is important in preschool period and for the problem analysis and establishing cause-effect relationships, fishbone diagram is an effective and simple tool for children (Birbili, 2006). Brainstorming, or idea storming, is a tool that promotes creative thinking that allows a large number of ideas to be generated in a short time (Öztürk, 2009). Brainstorming is one of the cognitive tools as a discussion and a technique of producing original ideas (Hartman, 2002). If a schema (visual material) is created in the activity and the resulting ideas are written to the arms of this diagram, it can be included in schematic organizers. Brainstorming is an effective tool in preschool period, especially in learning mathematics, it promotes stronger performance (Ryoo, Molfese, \& Brown, 2018). Thus, it will be a great way to enhance producing alternative problem solutions. Flowchart is a diagram that illustrates an algorithm, workflow or process, or a systematic solution of a problem by connecting various geometric shapes with arrows (Sevocab, 2016). The ability that is closely related to intrinsic motivation in problem solving is not to distract attention during solution and to provide flow in systematic order (Davidson, 2003). Flowchart is also classified as a fishbone diagram by Dexter and Hughes (2011). The child's flowchart will reveal the alternative solution methods in a single visual, and it will cause the algorithmic thinking ability, which is the basis of problem solving. Main purpose of using flowchart in preschool is that children are just learning how to read and write in this period so it is vitally important to guide them with shapes in decision making processes. 


\section{Method}

\section{Research Design}

Case study was employed in this study. In the case study, factors related to a situation (environment, individuals, events, processes) are explored through a holistic approach and focused on how they affect the situation and how they are affected by the situation. Yin (1984) defines case study as used in cases where there is more than one source of data and a current phenomenon is being worked within its own reality. According to classifications made by Yin (1984), this study uses a holistic single case design (Yildırım \& Şimşek, 2006). The unit of analysis used in this study is computer-aided and algorithm-based face-to-face learning and problem-solving activities for preschool children. Scientific contribution of the case study is that it is a method of discovery (Shaughnessy, Zechmeister \& Zechmeister, 2008). Long-term interaction was provided to generalize the results of the study. Both qualitative and quantitative data were collected from the participants. The study was conducted in the field of educational technologies. The questions of "why" and "how" are asked in educational technology research. Same questions apply to case studies. Therefore, use of case studies in educational technologies is quite common (Willis, 2008).

\section{Participants}

Study group consisted of 28 preschool children who were 60-72 months and studying in a state preschool in Ankara/Turkey (Permissions from children's families and from the related department of Ministry of Education were obtained because of the children age group). Activities were planned to be carried out are not suitable for the development characteristics of children before 60 months. Thus, only children over 60 months and over were preferred for purposeful sampling. There are two classes in the study school and activities were held in both classes. One class consists of 15 children ( 8 boys, 7 girls) and the other one consists of 13 children (7 boys, 6 girls). There is a homogeneous distribution in terms of gender. Interpretivism and critical theory, two basic paradigms of qualitative research, emphasize the importance of conducting research within its "own context" (Willis, 2008). Thus, it was decided to carry out the study in children's own classes. It is assumed that all children in the study have similar developmental characteristics according to the acquisition range determined by Preschool Education Curriculum. 
Activity

Researcher undertook the role of implementing the activities. "Ilk Garaj" software was used in the study. There are 25 algorithmic thinking and semi-coding activities for preschool in this software. Activities were organized in collaboration with experts from instructional technology and preschool education fields. The activities of this software are given in Table 1 according to problem-solving steps.

Table 1. Problem-Solving Steps and Ilk Garaj Activities

\begin{tabular}{ll}
\hline Problem-Solving Steps & Ilk Garaj Software Activities \\
\hline $\begin{array}{l}\text { Presentation of the problem (Logical arrangement and } \\
\text { analysis of data, abstraction) }\end{array}$ & $\begin{array}{l}\text { Understanding the Problem } \\
\text { (Visual presentation and } \\
\text { question-answer activity) }\end{array}$ \\
\hline $\begin{array}{l}\text { Analysis of the problem (Presenting the data with } \\
\text { visual materials, models or simulations, defining } \\
\text { cause-effect relations) }\end{array}$ & $\begin{array}{l}\text { Analyzing the Problem (Fish- } \\
\text { bone activity) }\end{array}$ \\
\hline $\begin{array}{l}\text { Production of alternative solutions (Defining and } \\
\text { analyzing the possible solutions, compiling the most } \\
\text { efficient and effective steps) }\end{array}$ & $\begin{array}{l}\text { Producing Alternative } \\
\text { Solutions to the Problem } \\
\text { (Brainstorming activity) }\end{array}$ \\
\hline $\begin{array}{l}\text { Automation of the solution with algorithmic thinking } \\
\text { (Presenting the solution with a series of steps) }\end{array}$ & $\begin{array}{l}\text { Planning the Optimum } \\
\text { Solution (Flowchart activity) }\end{array}$ \\
\hline
\end{tabular}

Ilk Garaj works in an online learning management system on any web browser. Teacher logs in the system with username and password, and reflects the activities on the screen/whiteboard via projection device and allows children to follow the activities. In one activity, there are approximately 6-8 slides in each of the four main sections (understanding the problem, cause-effect relations, alternative solutions, planning of solutions). There are 2432 slides in each activity. Sample screen were given in Figure 1.

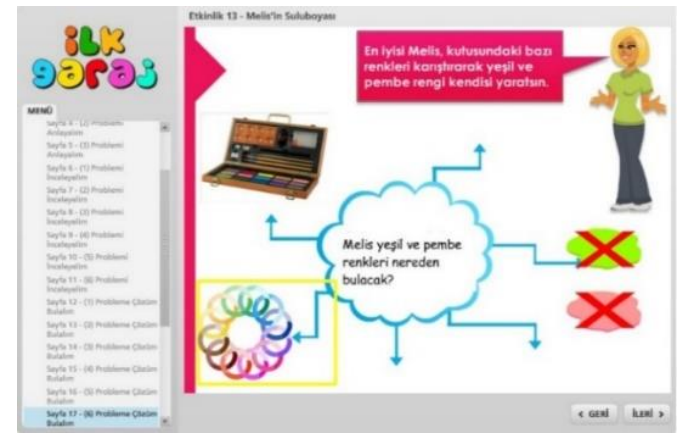

Figure 1. Brainstorming (Producing alternative solutions) activity.

Since the duration of the study covers a semester period of about 13 weeks, it was considered appropriate by field experts and researchers to conduct activities between 10-12 
weeks. The fact that the study was a qualitative study made it necessary to have a long-term interaction not completely sufficient but enough for trustworthiness of data. According to the principle of easy to difficult, the concepts in activities must be taught in a simple way that children can understand (Schunk, 2011). Ten activities used in the study were chosen by researchers as easy to difficult (Traffic lights, sharing the apples, tooth care, flower care, tablet computer, watercolors, old technological devices, gifts, guest from China, lost in mall). Evaluation activity (offended at friend) was determined independently from the activity (classroom) environment. Each activity starts with understanding the problem. As an example, in the second activity (sharing the apples), a mother wants to share three apples to her two children. This problem situation is given to children with visual and verbal presentation by researcher. Then in the fishbone activity, children analyze the problem and establish cause-effect relations. There is a symbol stands for "justice" at the end of the fishbone and researcher asks children about what happens when mother gives one apple to her child and two apples two another etc. Then brainstorming slides come. Researcher asks and children answer about alternative solutions for how to share three apples for two children. Researcher gets answers and show alternate solutions to children and at the end, gives the optimum solution. Here, the important thing is that there is not only one solution. Children's answers are approved by researcher but for the flowchart activity, we need an optimum solution to solve it step-by-step with flowchart diagram. One and a half apple for each children is the optimum solution for this problem. In the last section, researcher gives activity sheets and flowchart stickers to children and they paste the diagrams according to the solution. Researcher shows the correct flowchart steps at the end of the activity.

\section{Data Collection}

There are two main data collection processes. One of them is the verbal data of children during the problem solving activities. Verbal data was recorded with video camera and transferred to transcripts. Second one is flowchart that shows the problem solution process of children as mentioned in method part. In order to determine how much participation and interaction in each step of problem-solving activities, all verbal data related to classroom interaction are needed. In the participatory observation, researcher collects firsthand data and tries to contribute to data sources (Çepni, 2005). Researcher contributed to data sources by ensuring the implementation of activities. Video camera recording and 
transfer of these records to transcripts were performed to analyze the data. Twenty camera records of 10 activities were recorded for each class. The video camera is positioned to show the classroom and researcher. All camera records were tracked by researcher and transferred to transcripts. In the process of transferring to transcripts, the method of transferring the interactions of discourse analysis technique to the transcripts was used. In the transcripts, the studies of researchers who had previously conducted classroom discourse analysis (Brooks, 2008; Cazden, 1988) were used.

It is important for students to learn by doing their own graphical organizers in order to encourage more learning (Sweller, 1999). During the study, 245 flowcharts were collected because of children's absences on some days. A flowchart evaluation form was prepared by researchers and presented to expert opinion. The flowchart evaluation form was finalized by examinations of two field experts and three preschool education experts. The use, layout and flow direction of the forms were discussed. Moreover, a scoring was determined for coloring but preschool education experts stated that scoring could not be used for coloring. Preschool experts also stated that draw and paste activities are important for children. Thus, the final flowchart evaluation form consists of five dimensions: In the first three dimensions, flowcharts prepared by the children are scored. Correct use of shapes used in the flowchart, correct placement of shapes and correct flow direction are examined. The determination of scores was finalized with expert opinions. Scoring is defined as zero (no/none), one (insufficient), two (partially sufficient) and three (sufficient). The highest score is nine. Other dimensions are the correction status and the missing/over-use. These dimensions were coded as yes/no and the development status of children at the end of all activities was examined.

\section{Evaluation Study}

After completion of 10 activities, in order to evaluate children's use of cognitive tools such as fishbone, brainstorming and flowchart, evaluation study was conducted in groups of three in a separate place independent from classroom. Class-independent word means the reduction of the number of groups and the environment where Ilk Garaj software is not used. In the evaluation study where there is no online content in order to provide students with mutual ideas while establishing cause-effect relations and brainstorming, the number of groups has been reduced in order to obtain more detailed data. Since these activities do not constitute a challenge for researcher to keep notes, camera recording is not needed. Instead, 
Çetin $\mathcal{E}$ Özdemir

researcher recorded children's responses manually to the forms of fishbone and brainstorming schemes on paper. The answers to the questions were evaluated individually. Records in the evaluation study were transferred to transcripts, such as camera recordings, under the title of Evaluation Study. Flowchart working papers were also subjected to the flowchart evaluation form.

\section{Data Analysis}

\section{Discourse Analysis and Transcripts}

Discourse analysis was employed in order to analyze the verbal data of children in classroom environment. Because of the participants are in early ages, they talk a lot in classroom environment and it is hard to make observation with form or something else during the lecture. Video records gave all the verbal data to transcripts and discourse analysis gave the key sentences (as mentioned later) for problem solving process. Discourses can be considered as individuals using language to create meaning within the social context (Cohen, Manion \& Morrison, 2005). Similar to content analysis, discourse analysis technique is used to analyze the language that individuals use in social environment in more depth. Johnstone (2003) argues that discourse analysis reflects the everyday language of speech better, and should be supported by content analysis. Cazden (1988), who has made significant contributions to the discourse of classroom interaction, suggests that interaction between children and classroom is different from outside, and that researchers can use these texts in educational field. Because the discourse in classroom is under the supervision of a teacher and even if activities involve real-life problems, that interaction becomes an academic one.

Transcripts were prepared according to the IRE model that Cazden (1988) used in classroom interaction. IRE consists of initials of the words initiation, response and evaluation. According to this model, teacher initiates the classroom interaction. MaxQda 10 qualitative data analysis software was used in the coding of transcripts. Code system was prepared according to problem-solving steps that constitute the basis of the study and interactions to be considered in discourse analysis. All of the transcripts were uploaded to MaxQda 10 and then code system was created as specified. The prepared code system is shown in Table 2. 
Table 2. Code system

\begin{tabular}{lc}
\hline Code System & Total Interaction \\
\hline Problem Situation & \\
Definition & 136 \\
Causes & 179 \\
Effects & 42 \\
Solution Advice & 148 \\
\hline
\end{tabular}

Table 2 indicates that Problem Situation shows the main purpose of the study and stages of children's expressions in class interactions. Figure 2 shows an example-coding pattern from MaxQda software.

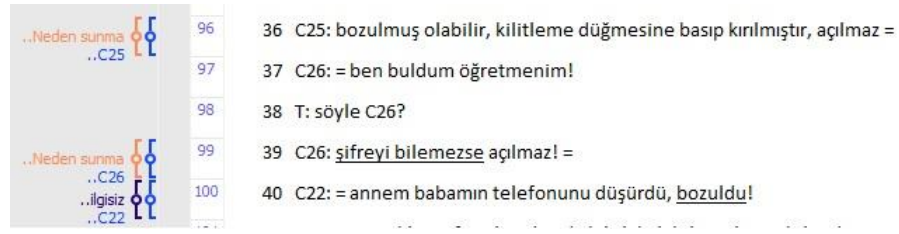

Figure 2. Sample coding

In the transcripts, at the beginning of each speech, it was stated that the expression belongs to whom. Each statement is assigned to the owner's name (Coded as $\mathrm{C} 1, \mathrm{C} 2 \ldots$ to C28). In this way, it is easily obtained when making an analysis that a sentence belongs to whom. In each theme, how much of the children are included were shown with numerical data and visual diagrams with the help of code-matrix relations browser of MaxQda analysis program.

\section{Flowchart Analysis}

A total of 245 flowcharts of 10-week activities were scored by researcher and it was presented to an independent field expert for evaluation, in order to be a neutral assessment and to ensure reliability. The large number of flowcharts was a challenge for an independent field expert. Thus, 49 flowcharts of the first 2 weeks were evaluated by the expert. The points given by researcher and independent expert to 49 flowcharts of the first two weeks were subjected to Pearson correlation analysis. The correlation coefficient was $0.773(\mathrm{p}<0.01)$. If the correlation coefficient is greater than 0.7, relationship between the variables is high (Köklü, Büyüköztürk \& Çokluk, 2007). As the points given by researcher and field expert showed a high level of correlation, remaining flowcharts (196) were evaluated only by researcher. Mean scores of 10 weeks were determined for the flowcharts prepared by children. In the evaluation study, 28 flowcharts prepared for only one activity. Scoring was done by 
researcher and two experts and the average of scores given by three people has made the scoring more reliable.

\section{Findings}

Problem-Solving Situations of Preschool Children (10-week period)

Expressions of children in classroom interaction were coded as stated in the activity. In this way, children's sentences to understanding the problem, possible reasons and results when analyzing the problem sentences and solution suggestions they presented to the problem were taken into consideration. In the systematic planning of problem solving, flowcharts prepared by children were scored. Findings related to the activities performed with these cognitive tools are given below.

\section{Understanding the Problem, Problem Analysis and Solution}

Statements of children, which were coded as Definition in MaxQda, were taken into consideration in this section. Children's participation in interactions is often related to problem-related events with their own words. These sentences indicate that children give attention to the subject; they give explanations about the subject, make comments and try to give information about the problem situation to their friends and teacher. In the process of understanding the problem, total number of interaction is 136. Only two children (C7, C23) out of 28 did not interact at this stage. Sample statements from children are given below:

- $\quad$ Traffic lights exist so traffic accidents do not occur (traffic lights activity)

- If there are 3 apples for two children, one is more (sharing the apples activity)

- My mother does not care her teeth, now she has toothache (tooth care activity)

- $\quad$ The flower on the screen is dead (flower care activity)

Participation of children in the interactions between cause-effect relations is usually determined by the answers to the questions of teacher, showing the problem state at the end of fishbone diagram and asking, "What causes this situation" or "What happens as a result of this situation". In the study of cause-effect relations of the problem, total number of interaction in is 221. Two children $(C 2, C 23)$ did not interact at this stage. Sample statements from children are given below:

- If somebody pores water on the road, there would be an accident (traffic lights activity)

- If she gives all the apples to one child, there would be an injustice (sharing the apples activity) 
- If we eat a lot of candy, our teeth would be damaged (tooth care activity)

- If we do not put the flower to the sunlight, it will fade (flower care activity)

Considering the problem analysis and the use of fishbone diagram, the number of children interacting by using fishbone diagram in order to establish cause-effect relations and the number of interacting with the questions asked by teacher increase. Distribution of the number of interactions in the class also progressed to a more acceptable level. Here, it can be said that the use of the fishbone diagram, which is a schematic organizer, has an effect on the participation of children in the interaction. Both the increase in the number of interactions and the normalization of distribution to the form the idea of using fishbone diagram to establish the cause-effect relation of the problem.

In this brainstorming section, the statements coded as solution suggestion were taken into consideration. The participation of children in interactions is often determined by the answers to their questions such as whether to do this or how to solve this problem. The solution proposals from children were taken without any judgment. In the process of producing alternative solutions to the problem, the total number of interaction is 148. Two children $(C 7, C 8)$ did not interact at this stage. Sample statements from children are given below:

- He has to stop in the red light whether there is a car or not (traffic lights activity)

- She can divide the third apple into two pieces for two children (sharing the apples activity)

- We should use a smaller brush then our parent's (tooth care activity)

- We should put the flower to the sunlight (flower care activity)

Considering the alternative solutions, the number of children using brainstorming diagram and responding to questions decreased compared to previous activity. Distribution of numbers of interaction in the classes became more acceptable. It is observed that children with extreme numbers in interaction have decreased. It can be said that the use of brainstorming, which is a schematic organizer, has an effect on children's participation in interaction. However, this interaction is limited compared to cause-effect relations. It was observed that children were detached and started to act independently after a certain period in video camera records. The use of brainstorming technique for collecting as many solutions as possible in order to produce alternative solutions to problem situations is appropriate for preschool. However, lack of attention and motivation in children should not be ignored. 


\section{Flowchart Use of Children}

Children have created their own flowcharts during the step-by-step planning of the most appropriate solution to the problem. Descriptive statistics related to the average scores of flowchart preparation are given in Table 3.

Table 3. Flowchart activity descriptive statistics

\begin{tabular}{lcccccc}
\hline & $\mathrm{N}$ & Mean & Median & s.d. & Min. & Max. \\
\hline Flowchart & 28 & 7.30 & 7.40 & .971 & 5.2 & 8.85 \\
\hline
\end{tabular}

The highest possible score from a flowchart is nine. In Table 3, the arithmetical average of the children's flowchart scores was 7.30 in the evaluations made by the researcher. Scores of the absent children in the activity held in that week were not taken into consideration. All children were evaluated according to the number of flowcharts they made. Table 3 shows that standard deviation is 0.971 . This value shows that children do not differ too much from each other. Considering the step-by-step planning and flowchart activities, it is observed that children's requests and interest in preparing a flowchart have not decreased during the 10-week activities. Although problem situations and solution planning became more difficult as weeks progressed, it was revealed that the observed scores of children did not show much differentiation. Considering that the highest score that can be obtained from the flowchart evaluation form is nine, there is a success rate of around $81 \%$ in the case of flowchart use throughout the classes. Children learned flowchart shapes, how they were placed on paper and how the flow was provided with arrows before the activities started. Nevertheless, it is seen that the level of completing flowcharts of children is high even in the first activities. This shows that flowchart, which is a cognitive tool as a schematic organizer, can be used in preschool period.

\section{Problem-Solving Situations of Preschool Children in an Independent Environment}

'Offended' activity was made as problem condition in the evaluation study. According to the problem situation, two friends have offended each other and our hero is asked to reconcile these friends. According to the observations made, when children were told about the problem situation, they discussed the problem situation among themselves. When asked about which tools to use for problem analysis and problem solving, all of the children expressed fishbone and brainstorming tools. These findings indicate that children have the habit of using cognitive tools when they encounter a problem state. Children were 
not told what shapes to use while preparing flowcharts. For instance, when the researcher says that 'we now have to decide to implement the solution', the children themselves have said that 'the diamond shape will be used' and the sticky diamond slice in front of them has glued to the paper. At this stage, it was seen that whether children learned flowchart shapes or not. Table 4 and Table 5 present the understanding of the problem, problem analysis and brainstorming expressions of children in the evaluation studies. (Data is separated into two pieces according to the classes).

Table 4. Evaluation activity children participation (Class 1)

\begin{tabular}{llllllllllllllll}
\hline Activity & C1 & C2 & C3 & C4 & C5 & C6 & C7 & C8 & C9 & C10 & C11 & C12 & C13 & C14 & C15 \\
\hline $\begin{array}{l}\text { Understanding } \\
\text { the problem }\end{array}$ & 2 & 1 & 1 & 1 & 2 & 2 & 1 & 1 & 1 & 1 & 2 & 1 & 2 & 1 & 1 \\
$\begin{array}{l}\text { Problem analysis } \\
\text { Alternative }\end{array}$ & 2 & 3 & 4 & 3 & 2 & 2 & 2 & 2 & 3 & 2 & 3 & 3 & 3 & 2 & 3 \\
solution & 1 & 2 & 2 & 2 & 2 & 1 & 1 & 1 & 2 & 2 & 3 & 2 & 1 & 2 \\
\hline Total Interaction & 5 & 5 & 7 & 6 & 6 & 6 & 4 & 4 & 5 & 5 & 7 & 7 & 7 & 4 & 6 \\
\hline
\end{tabular}

Table 5. Evaluation activity children participation (Class 2)

\begin{tabular}{|c|c|c|c|c|c|c|c|c|c|c|c|c|c|}
\hline Activity & $\mathrm{C} 16$ & $\mathrm{C} 17$ & $\mathrm{C} 18$ & $\mathrm{C} 19$ & $\mathrm{C} 20$ & $\mathrm{C} 21$ & $\mathrm{C} 22$ & $\mathrm{C} 23$ & $\mathrm{C} 24$ & $\mathrm{C} 25$ & $\mathrm{C} 26$ & $\mathrm{C} 27$ & $\mathrm{C} 28$ \\
\hline $\begin{array}{l}\text { Understanding } \\
\text { the problem }\end{array}$ & 1 & 1 & 1 & 1 & 2 & 1 & 1 & 1 & 1 & 2 & 1 & 1 & 1 \\
\hline Problem analysis & 3 & 2 & 2 & 2 & 2 & 2 & 2 & 2 & 2 & 2 & 2 & 2 & 2 \\
\hline Alternative & 2 & 1 & 1 & 3 & 2 & 2 & 3 & 3 & 2 & 2 & 3 & 3 & 1 \\
\hline \multicolumn{14}{|l|}{ Solution } \\
\hline Total Interaction & 6 & 4 & 4 & 6 & 6 & 5 & 6 & 6 & 5 & 6 & 6 & 6 & 4 \\
\hline
\end{tabular}

Considering the Table 4 and 5, participation of children in interaction in problem solving is quite close to each other. All children interacted in problem-solving activities in an independent environment and realized problem relations, found the cause-effect relations, and presented solutions to the problem. Some children appear to be prominent in the number of interactions. Participation of all children in the problem state interactions shows that they can use question-answer and cognitive tools in the problem state activities but they can remain behind when the opportunity is not given in the classroom environment. The findings revealed the accuracy of the purpose of collecting detailed data on a child basis. Children who internalize the problem solving process have expressed themselves in a lower number in groups.

The most striking point in this data is that children who are under the continuous average and do not interact at all in 10-week long problem understanding, fishbone and 
brainstorming activities, have interacted in the class-independent environment. In particular, C16 seems to be ahead of some children in class-independent setting. In the class interactions, it was found that the children who were left behind, and sometimes did not interact at all, were slightly less than their friends in the evaluation study of children numbered C1, C2, C6, C7, C8, C10, C14, C16, C17, C21, C22, C23, C24 and C28. C23, which has a high number of absence, C6 and C16 are behind all of the friends in all activities, but they have higher values than their friends and even higher than them in the classindependent environment.

Findings obtained in evaluation study also reveal the difference in the use of cognitive tools in problem-solving activities in interactions within the classroom and in the class-independent environment. Although children participate in interactions at certain levels according to their own developmental characteristics, they can stay behind in the classroom. This does not mean that they stay away from activities. Children who answered the questions addressed to them in independent evaluations also showed that they participated in fishbone and brainstorming activities and used these schematic organizers. Based on the literature in which children's speech is constantly emphasized (Vygotsky \& Luria, 1994), these findings encouraged children to interact when they are given the opportunity to interact with the problem situation and express their ideas. What is important here is the correct communication of information about the problem situation with the help of external mediators in the guidance and coaching of the teacher. Activities conducted in the technology-supported environment provide an environment suitable for children to express themselves.

All of the flowcharts (28) in the evaluation study were evaluated by researcher and two independent experts for the reliability of data. The descriptive statistics of the flowcharts are given in Table 6.

Table 6. Evaluation study flowchart descriptive statistics

\begin{tabular}{lcccccc}
\hline & $\mathrm{N}$ & Mean & Median & s.d. & Min. & Max. \\
\hline Flowchart & 28 & 8.12 & 8 & .788 & 5.66 & 9.00 \\
\hline
\end{tabular}

Table 6 indicates that the class average is quite high (8.12) and the standard deviation is low (0.788). Scores show a normal distribution between 5.66 and the highest value of 9 . Table 7 and Table 8 present the evaluation of the flowcharts of children in evaluation activity. 
Table 7. Evaluation study flowchart scores (Class 1)

\begin{tabular}{lllllllllllllllll}
\hline Activity & C1 & C2 & C3 & C4 & C5 & C6 & C7 & C8 & C9 & C10 & C11 & C12 & C13 & C14 & C15 \\
\hline Researcher & 9 & 9 & 8 & 7 & 9 & 8 & 8 & 8 & 9 & 8 & 9 & 7 & 9 & 8 & 9 \\
Expert 1 & 8 & 9 & 8 & 9 & 9 & 8 & 8 & 8 & 9 & 8 & 9 & 7 & 9 & 8 & 9 \\
Expert 2 & 8 & 9 & 8 & 9 & 9 & 8 & 8 & 8 & 9 & 8 & 9 & 7 & 9 & 8 & 9 \\
\hline Mean & 8.3 & 9 & 8 & 8.3 & 9 & 8 & 8 & 8 & 9 & 8 & 9 & 7 & 9 & 8 & 9 \\
\hline
\end{tabular}

Table 8. Evaluation study flowchart scores (Class 2)

\begin{tabular}{llllllllllllll}
\hline Activity & C16 & C17 & C18 & C19 & C20 & C21 & C22 & C23 & C24 & C25 & C26 & C27 & C28 \\
\hline Researcher & 7 & 9 & 8 & 8 & 9 & 9 & 7 & 7 & 7 & 8 & 7 & 6 & 8 \\
Expert 1 & 8 & 8 & 8 & 8 & 9 & 9 & 9 & 8 & 7 & 8 & 7 & 6 & 9 \\
Expert 2 & 8 & 8 & 8 & 8 & 9 & 9 & 8 & 7 & 7 & 8 & 8 & 5 & 9 \\
\hline Mean & 7.7 & 8.3 & 8 & 8 & 9 & 9 & 8 & 7.3 & 7 & 8 & 7.3 & 5.7 & 8.7 \\
\hline
\end{tabular}

In Table 7 and 8, the evaluations of researcher and independent experts differ in nine children. The absence of a child with a score below 7 points other than one child (C27) indicates that the level of completion of flowcharts is high. C12, whose average of flowchart evaluation was 5.20 in the 10-week activities, showed that even if it was below the average, C12 could produce the flowchart on its own. However, C27, which is generally below the average in the classroom interaction, is lowering the class average with an average of 5.66 in the independent evaluation study. There is no child below seven points instead of C27.

Findings of the study show that $90 \%$ of the use of flowcharts of children has been successful in an independent study. During 10-week activities, children prepared flowcharts by looking at the screen when needed. In this process, researcher support has always been with children. At the same time, according to the observations of researcher, children received help from each other and interacted with each other while creating flowcharts. In the activity-independent environment, it is seen that children can create flowcharts themselves in the absence of such support in their problem-solving evaluations. In this case, after 10 weeks of activities, children internalized this process. Analysis of the data of evaluation study shows that children use cognitive tools because of long-term cognitive tools use in teacher-assisted environment. Moreover, after the activities, children internalized the process of thinking when they are on their own and can use it when it is necessary. These data show that schematic organizers such as fishbone, brainstorming diagram and flowchart, which are cognitive tools, can be used in preschool. These findings are consistent with study data on the inclusion of ICT in preschool education (Cviko et al., 2014; Dong \& Newman, 
2016; Lin, 2012). ICT use is added to the curriculum as a model, and accepted by children and teachers in classroom activities in the mentioned studies.

\section{Discussion}

Findings of the study revealed that, problem-solving activities prepared with graphical organizers and ICT-supported environment are appropriate for preschool children. Children actively participated to the activities of understanding the problem, examining the cause-effect relations, producing alternative solutions to problem activities, and they expressed their thoughts. Neville (2007) states that, children between 5 and 6 years old keep their attention for 10-15 minutes in an activity. Children in these ages focus for 4-6 minutes when a task is given. It is stated that children can work or play in 10-25 minutes in a group. Since classroom activities with the teacher also comply with both the activity and the job description, a focus time of 10-15 minutes is mentioned (Neville, 2007). Video camera recordings during the activities range from 20 to 40 minutes in the study. The first 10-30 minutes of these periods are covered by understanding the problem, problem analysis and problem solving activities, and creating flowcharts in the last 10-15 minutes. Observations show the signs of children getting bored at the end of the activity of producing solutions to the problem during the first 3 activities, where children follow the screen and answer the questions of researcher. However, this period exceeds the specified duration of 10-15 minutes. As the software offers diversity to children in the visual field, interaction is ensured. Although observing boring or distractibility behaviors in children until the end of an activity, considering the average attention span of children at that age children's attention can be said to keep longer than normal. The children, who are looking at the projected image and interacting with teacher and friends, begin to create a flowchart before the effect of the visual support ends.

Considering the opinions that emphasize preschool children's problem solving (Ramani, 2005) and speech (Kinnucan, 2012; Vygotsky \& Luria, 1994) it is seen that the software is appropriate, and visual support and learning by doing effect children's attention. It is known that visual support and learning by doing is crucial for learning computer programming in early ages (Wakil, Khdir, Sabir \& Nawzad, 2019; Walshatri, Wakil, \& Bakhtyar, 2019), a basic step for introduction to problem solving. Scaffolding with visual support in classroom such as using interactive whiteboards enhances children's learning, 
conceptual understanding and accomplishing tasks (Maryam, Sören \& Gunilla, 2020) so their findings also show the crucial role of visual support in early childhood and also they are in consistent with this study's results.

Considering the use of schematic organizers of children, it is concluded that the software used is effective in this regard. According to the findings of the study, children comprehended activities they carried out starting from $2^{\text {nd }}-3^{\text {rd }}$ weeks and acted accordingly. Children who saw the fishbone image on the screen have said that they will do the fishbone activity and that they will look at the causes and consequences of the problem. Similarly, when they saw the image of brainstorming, they said that they would do brainstorming and produce solutions every week. These statements, which started to appear frequently after the first 3 weeks, show that children started to use cognitive tools with awareness. Children's learning by doing using cognitive tools was realized by preparing their own flowcharts. Paris and Winograd (1990) state that children become active tool users and constructors as they grow and develop. Considering the Vygotsky approach, children will have the ability to use cognitive tools at the end of the process. It is emphasized that the use of schematic organizers will involve children in the active learning process and that the creation of these tools will encourage them to learn more (Hong, Broderick \& McAuliffe, 2021). Results of this study support these views. Findings of the activity of independent problem solving evaluation showed that children used fishbone, brainstorming and flowchart tools related to the problem situation when they were on their own after 10 weeks of activities. This result supports the findings of studies show that advance organizers are important for children's learning and making (McDonald \& Vines, 2019). Social interaction is also a critical indicator in classroom environment and student with asocial behavior tend to avoid to complete the tasks they have given (Umay, 2019). However, opposite to those studies, this study revealed that children with asocial behavior in classroom environment showed success in independent problem solving activities. This is a result emphasizes the importance of using cognitive tools in problem solving.

There is a limitation on the use of fishbone and brainstorming activities in the classroom. In the use of the software in the classroom, it is largely the teacher's responsibility to ensure that the whole class interacts with fishbone and brainstorming activities. Children who remained silent in the classroom were found to use fishbone and brainstorming in their independent problem-solving assessments, that they were slightly behind those of their 
fellow students. According to Vygotsky, all mental processes are first found in a common area, and then go into the individual area (Bodrova \& Leong, 1996). Children who have less interaction were not able to develop sufficiently because they had little interaction in the common area. These results show that ICT-supported environments are never sufficient by themselves and there should always be the support and coaching of a teacher.

This is a study that children can use their thinking skills in an environment where schematic organizers (fishbone, brainstorm, and flowchart) are presented with the support of ICT. It has been observed in the studies that problem solving education in preschool improves children's problem solving skills (Alnıak \& Dinçer, 2005; Özbey \& Köyceğiz, 2020) and that children's thinking skills (algorithmic thinking, geometric thinking, problem solving) develop in ICT supported learning environments (Fessakis et al., 2013; Keren \& Fridin, 2014; Liu et al., 2013; Maryam, Sören \& Guilla, 2020). Preschool teachers believe and emphasize that using Web Technologies improve student learning, communication and sharing with parents (Alkhayat, Ernest \& LaChenaye, 2020). The application of this study both provided ICT support to preschool environment, and involved children actively as a process rather than an education in problem solving activities with cognitive tools. Transcript data containing verbal expressions obtained from the camera recordings show that children develop their thinking skills and that they can use original expressions at every stage of problem situations. According to Tonga and Tantekin-Erden (2020) preschool teacher candidates stated that skills which are required for problem solving and also dealing with problems in daily life is also crucial for the term "mindfulness" in early childhood. It is known that mindfulness enhances memory and academic skills in children (Lu, Huang \& Rios, 2017). Thus, the results of this study supports to develop mindfulness with problem solving activities in preschool.

Considering the activities of the Ilk Garaj software used in this study, it is appropriate and effective for gaining the cognitive, language, social and emotional and motor skills determined for the age group (60-72 months) of all activities. This result is an approvement of the finding that activities about social life skills such as problem solving, decision making improves the life skills of children in early ages (Topçu-Bilir, 2019). Considering the total interaction in the classroom, some of the activities may need some arrangements in the problem analysis stage. It can be said that software used in this study can be an effective problem-solving tool for preschool education. 


\section{Recommendations}

Considering the results, carrying a similar study may need more careful selection and sorting of activities from easy to difficult for a healthier progression of classroom interaction. Different cognitive tools (concept map, mind map, semantic maps, venn diagram etc.) can be used according to children's age and their developmental characteristics. This study revealed a case study within some limitations. Only qualitative research principles can be used to predict children's future behavior within the scope of this study. Conducting researches that are more extensive with higher numbers of participants or with different educational institutions will gain importance in terms of generalizability.

There are five developmental areas in preschool curriculum and cognitive domain was mentioned in this study. Problem solving activities can be distributed to other development domains (behavioral, emotional, psychomotor and language) and studies for each domain can be conducted. Preschool teachers and also parents should take into consideration problem solving activities in early ages with graphic organizers as an application recommendation. It is highly recommended to implement these activities to early childhood curriculum and also to early childhood teacher training programs.

Acknowledgement

The data used in this study was confirmed by the researchers that it belongs to the years before 2020. This study was produced from the first author's unpublished Ph.D. dissertation in the year of 2016. Second author is the advisor of that dissertation.

Author Contribution Statement

Ekmel ÇETIN: Conceptualization, methodology, activity implementer, data collection, data analysis, consultancy, writing and editing.

Selçuk ÖZDEMİR: Conceptualization, methodology, consultancy and control preliminary draft writing and editing.

\section{References}

Alkhayat, L., Ernest, J. \& LaChenaye, J. (2020). Exploring kuwaiti preservice early childhood teachers' beliefs about using web 2.0 technologies. Early Childhood Education Journal, 48, 715-725. https://doi.org/10.1007/s10643-020-01036-6

Allan, N. P., Hume, L. E., Allan, D. M., Farrington, A. L., \& Lonigan, C. J. (2014). Relations between inhibitory control and the development of academic skills in preschool and kindergarten: A meta-analysis. Developmental Psychology, 50(10), 2368-2379. 
Alnıak, Ş., \& Dinçer, Ç. (2005). Farklı eğitim yaklaşımları uygulayan okul öncesi eğitim kurumlarına devam eden çocukların kişiler arası problem çözme becerilerinin değerlendirilmesi [Evaluation of children's interpersonal problem solving skills who attend preschool education institutions that apply different educational approaches]. Ankara University Faculty of Educational Sciences Journal, 38(1), 149-166.

Angeli, C., \& Valanides, N. (2004). Examining the effects of text-only and text-and-visual instructional materials on the achievement of field-dependent and field-independent learners during problem-solving with modeling software. Educational Technology Research and Development, 52(4), 23-36.

Baralt, A. C. (2013). Ways digital scaffolds are used during collaborative problem solving in the preschool classroom (Unpublished Doctoral dissertation), University of Florida.

Birbili, M. (2006). Mapping knowledge: concept maps in early childhood education. Early Childhood Research \& Practice, 8(2), 1-10.

Bodrova, E., \& Leong, D. J. (1996). Tools of the mind: The Vygotskian approach to early childhood education. New Jersey, USA: Prentice-Hall.

Brooks, C. F. (2008). Exploring face-to-face and online classroom discourse: A case study of social roles as performed in a college course. (Unpublished PhD Thesis). University of California.

Cazden, C. B. (1988). Classroom discourse: The language of teaching and learning. Portsmouth, NH: Heinemann.

Cohen, L., Manion, L., \& Morrison, K. (2005). Research methods in education (5th ed). London: Routledge Falmer.

Cook-Cottone, C. P. (2004). Using Piaget's theory of cognitive development to understand the construction of healing narratives. Journal of College Counseling, 7(1), 177-186.

Cviko, A., McKenney, S., \& Voogt, J. (2014). Teacher roles in designing technology-rich learning activities for early literacy: A cross-case analysis. Computers $\mathcal{E}$ Education, 72, 68-79.

Çepni, S. (2005). Araştırma ve proje çalışmalarına giriş [Introduction to research and project studies] (2nd ed). Trabzon: Derya.

Davidson, J. E. (2003). Insights about insightful problem solving. In J. E. Davidson \& R. J. Sternberg (Ed.), The psychology of problem solving (pp. 149-175). New York: Cambridge

Dexter, D. D., \& Hughes, C. A. (2011). Graphic organizers and students with learning disabilities: A meta-analysis. Learning Disability Quarterly, 34, 51-72.

Dong, C. (2018). Preschool teachers' perceptions and pedagogical practices: Young children's use of ICT. Early Child Development and Care, 188(6), 635-650.

Dong, C., \& Newman, L. (2016). Ready, steady... pause: integrating ICT into Shanghai preschools. International Journal of Early Years Education, 24(2), 224-237.

Fessakis, G., Gouli, E., \& Mavroudi, E. (2013). Problem solving by 5-6 years old kindergarten children in a computer programming environment: A case study. Computers $\mathcal{E}$ Education, 63, 87-97.

Getzels, J. W. (1982). The problem of the problem. In R. Hogarth (Ed.), New directions for methodology of social and behavioral science: Question framing and response consistency (vol.11). San Francisco: Jossey-Bass.

Hartman, H. J. (2002). Developing students' metacognitive knowledge and skills. In H. J. Hartman (Ed.), Metacognition in learning and instruction. Dordrecht: Kluwer Academic.

Haywood, H. C. (2020). Cognitive early education. In Oxford Research Encyclopedia of Education.

Hong, S.B., Broderick, J.T. \& McAuliffe, C.M. (2021). Drawing to learn: A classroom case study. Early Childhood Education Journal, 49, 15-25. 
Howes, C., Unger, O. A., \& Matheson, C. C. (1992). The collaborative construction of pretend: Social pretend play functions. Albany: State University of New York.

Hsin, C.-T., Li, M.-C., \& Tsai, C.-C. (2014). The influence of young children's use of technology on their learning: A review. Educational Technology \& Society, 17(4), 85-99.

Ishikawa, K. (1968). Guide to quality control. Tokyo: JUSE.

Johnson, N. O. (2013). Kindergarten students solving mathematical word problems. (Unpublished PhD Thesis), Florida State University, Tallahassee, FL.

Johnstone, B. (2003). Discourse analysis. Malden, MA: Blackwell.

Jones, B. F., Pierce, J., \& Hunter, B. (1988/89). Teaching students to construct graphic representations. Educational Leadership, December/January, 27-31.

Keren, G., \& Fridin, M. (2014). Kindergarten Social Assistive Robot (KindSAR) for children's geometric thinking and metacognitive development in preschool education: A pilot study. Computers in Human Behavior, 35, 400-412.

Kinnucan, C. J. E. (2012). Developmental trends in preschoolers' use of prompted self-explanations to facilitate problem solving. (Unpublished PhD Thesis). Saint Louis University, Madrid.

Köklü, N., Büyüköztürk, Ş., \& Çokluk, Ö. (2007). Sosyal bilimler için istatistik [Statistics for social sciences] (2nd ed). Ankara: Pegem.

Lin, C.-H. (2012). Application of a model for the integration of technology in kindergarten: An empirical investigation in Taiwan. Early Childhood Education Journal, 40(1), 5-17.

Liu, E. Z.-F., Lin, C.-H., Liou, P.-Y., Feng, H.-C., \& Hou, H.-T. (2013). An analysis of teacherstudent interaction patterns in a robotic course for kindergarten children: A pilot study. The Turkish Online Journal of Educational Technology, 12(1), 9-18.

Lu, S., Huang, C., \& Rios, J. (2017). Mindfulness and academic performance: An example of migrant children in China. Children and Youth Services Review, 82, 53-59.

Maryam, B., Sören, H. \& Gunilla, L. (2020). Putting scaffolding into action: Preschool teachers' actions using interactive whiteboard. Early Childhood Education Journal, 48, 79 92. https://doi.org/10.1007/s10643-019-00971-3

McDonald, D., \& Vines, R. (2019). Flipping advanced organizers into an individualized meaning-making learning process through sketching. Teaching Artist Journal, 17(1-2), 51-61.

Ministry of National Education [MoNE] (2013). Milli eğitim bakanlığı, öğretim programlarını izleme ve değerlendirme sistemi. Okul öncesi eğitim programı. [Online: Retrieved from https://mufredat.meb.gov.tr/ProgramDetay.aspx?PID=652].

Neville, H. F. (2007). Is this a phase? Child development $\mathcal{E}$ parent strategies, birth to 6 years. Seattle, USA: Parenting.

Nikolopoulou, K. (2020). Preschool teachers' practices of ICT-supported early language and mathematics. Creative Education, 11(10), 2038-2052.

Özbey, S. \& Köyceğiz, M. (2020). A study on the effect of the social skill education on the academic self respect and problem solving skills of the pre-school children. International e-Journal of Educational Studies, 4(8), 176-189. DOI: 10.31458/iejes.727590

Öztürk, A. (2009). Kalite yönetimi ve planlaması [Quality management and planning]. Bursa: Ekin.

Paris, S. G., \& Winograd, P. (1990). How metacognition can promote academic learning and instruction. In B. F. Jones \& L. Idol (Ed.), Dimensions of thinking and cognitive instruction. Hillsdale, NJ: Lawrence Erlbaum.

Pretz, J. E., Naples, A. J., \& Sternberg, R. J. (2003). Recognizing, defining and representing problems. In J. E. Davidson \& R. J. Sternberg (Ed.), The psychology of problem solving (pp. 3-30). Cambridge, United Kingdom: Cambridge University. 
Ramani, G. B. (2005). Cooperative play and problem solving in preschool children. (Unpublished PhD Thesis). University of Pittsburgh, Pittsburgh.

Rogoff, B. (1998). Cognition as a collaborative process. In D. Kuhn \& R. S. Siegler (Ed.), Handbook of child psychology: Cognition, perception and language. NY: J. Wiley.

Ryoo, J. H., Molfese, V. J., \& Brown, E. T. (2018). Strategies to encourage mathematics learning in early childhood: Discussions and brainstorming promote stronger performance. Early Education and Development, 29(4), 603-617.

Schunk, D. H. (2011). Öğrenme teorileri [Learning theories]. Ankara: Nobel.

Schewebel, M., \& Raph, J. (1973). Piaget in the classroom. NY: Basic Books.

Sevocab. (2016). Software and systems engineering vocabulary. [Online: Retrieved from https://pascal.computer.org/sev_display/search.action]

Sezgin, E., \& Ulus, L. (2020). An examination of self-regulation and higher-order cognitive skills as predictors of preschool children's early academic skills. International Education Studies, 13(7), 65-87.

Shaughnessy, J. J., Zechmeister, E. B., \& Zechmeister, J. S. (2008). Research methods in psychology (8th ed). New York: McGraw-Hill.

Sweller, J. (1999). Instructional design in technical areas. Camberwell, Australia: ACER.

Tonga, F., \& Tantekin-Erden, F. (2020). Mindfulness: Views of Turkish pre-service early childhood teachers. International e-Journal of Educational Studies, 4 (8) , 122-137.

Topçu-Bilir, Z. (2019). Yaşam becerileri eğitim programının beş yaş çocuklarının yaşam becerileri, benlik algıları ve sosyal duygusal uyum düzeylerine etkisi. (Yayımlanmamış Doktora Tezi). Hacettepe Üniversitesi Eğitim Bilimleri Enstitüsü, Ankara.

Umay, U. H. (2019). 60-72 aylık çocukların sosyal becerilerinin problem çözme becerilerini yordama gücü. (Yayımlanmamış Yüksek Lisans Tezi). Akdeniz Üniversitesi, Eğitim Bilimleri Enstitüsü, Antalya.

Vygotsky, L. S. (1978). Mind in society: The development of higher psychological processes. Cambridge, MA: Harvard University.

Vygotsky, L. S., \& Luria, A. R. (1994). Tool and symbol in child development. In R. V. d. Veer \& J. Valsiner (Ed.), The Vygotsky Reader (pp. 99-174). Oxford: Blackwell.

Wakil, K., Khdir, S., Sabir, L., \& Nawzad, L. (2019). Student ability for learning computer programming languages in primary schools. International e-Journal of Educational Studies, 3(6), 109-115. DOI: 10.31458/iejes.591938

Walshatri, S.H.H., Wakil, K., \& Bakhtyar, R. (2019). The difficulties of theoretical and applied learning for mathematics subject in primary schools. International e-Journal of Educational Studies (IEJES), 3(6), 141-149. DOI: 10.31458/iejes.591997

Willis, J. W. (2008). Qualitative research methods in education and educational technology. Charlotte, NC: Information Age.

Yıldırım, A., \& Şimşek, H. (2006). Sosyal bilimlerde nitel araştırma yöntemleri [Qualitative research methods in social sciences]. Ankara: Seçkin.

Yin, R. (1984). Case study research. Beverly Hills: Sage Publication.

Zollman, A. (2009). Students use graphic organizers to improve mathematical problemsolving communications. Middle School Journal, 41(2), 4-12.

Copyright $(\mathrm{C} J C E R$

JCER's Publication Ethics and Publication Malpractice Statement are based, in large part, on the guidelines and standards developed by the Committee on Publication Ethics (COPE). This article is available under Creative Commons CC-BY 4.0 license (https://creativecommons.org/licenses/by/4.0/) 